\title{
Addiction, Intoxicants, and the Humoral Body
}

\author{
Phil Withington \\ Department of History, University of Sheffield, UK \\ Email: p.withington@sheffield.ac.uk
}

\begin{abstract}
Taking the humoral body as its spatial focus, this article considers how medical writers and practitioners engaged with 'intoxicants' both in terms of the prescription of medicines and in the conceptualization of compulsive consumption - or what is often styled by modern practitioners as 'addiction'. Focusing in the first instance on the compilers of vernacular pharmacopoeia - compilations of medical ingredients and techniques - the article argues that just as sugar, tobacco, and especially opiates had a significant and possibly transformative role in everyday physic, so the 'operation' of opiates, distilled spirits, and tobacco was crucial in stimulating new thinking about how bodies became substance-dependent. The article also argues, however, that, in order to conceptualize the problem, writers turned to the venerable language of custom rather than the relatively new language of addiction - in particular, the ancient idea of custom as 'second nature'.
\end{abstract}

'Whatsoever a Man gives himself unto, that he becomes strong in, be it either good or evil' - so warned the popular health and lifestyle writer Thomas Tryon, in $1691 .^{1}$ Tryon went onto explain that

if it be to drink more than need and Nature requires, he will in a little time come both to expect and need it; the like, if it be Drink that is improper, as Brandy, Wine, or the like; nay, if it be Coffee or Tea, if a Man be not wary, the use of it shall enslave him, so that he shall not know how to be without, and from drinking it moderately, he shall by degrees, and as it were insensibly slip into excess; and the very same thousands can experience of Tobacco. ${ }^{2}$

\footnotetext{
${ }^{1}$ Thomas Tryon, Wisdom's dictates, or, aphorisms \& rules, physical, moral, and divine, for preserving the health of the body, and the peace of the mind (London, 1691), p. 128.

${ }^{2}$ Ibid.

(c) The Author(s), 2021. Published by Cambridge University Press. This is an Open Access article, distributed under the terms of the Creative Commons Attribution licence (http://creativecommons.org/licenses/by/4.0), which permits unrestricted re-use, distribution, and reproduction, provided the original article is properly cited.
} 
Modern conceptions of addiction, rooted in medical expertise, tend to view dietary dependencies as the product of physiological and involuntary processes rather than simply a failure of will, responsibility, or morality. Tryon's depiction of compulsive and reflexive consumption ('shall enslave him', 'insensibly slip into excess') clearly resonates with this view; so, too, his intimation that certain substances can transform 'natural' and controllable desires into unnatural and immoderate needs.

As such, his observations sit awkwardly alongside the historiography of 'addiction' as it has developed since H. G. Levine's seminal 1978 article on 'The discovery of addiction'. ${ }^{3}$ They do so for three reasons. First, Tryon is preternaturally precocious. The burden of Levine's analysis was to show that it was in the 1780s that the medical writer Benjamin Rush 'organised the developing medical and common-sense wisdom' about habitual drunkards into 'the first modern conception of alcohol addiction'. ${ }^{4}$ Medical historians like Roy Porter have subsequently questioned the relative importance of individual physicians 'inventing' and implementing a modern paradigm in this way, pointing to the range of commentators characterizing 'addiction' as a disease and the convergence of factors that made the characterization socially and politically efficacious. ${ }^{5}$ But they have not questioned the focus on the eighteenth-century Enlightenment, one authoritative overview recently reiterating that the intellectual tools to formulate addiction as a 'disease' were 'more or less in place by the $1770 \mathrm{~s}^{\prime}{ }^{6}$ It is significant, then, that Tryon's writings on problematic consumption began to be published in the 1680 s and '90s, almost a century earlier.

Second, Tryon is anomalous discursively. Scholars like Jessica Warner and Rebecca Lemon have questioned the peculiar significance of the Enlightenment to the history of addiction, persuasively identifying analogous and nuanced discussions of habituated drunkenness in the sixteenth and seventeenth centuries. But they have done so by ignoring writings on 'physic' and focusing instead on moralistic and literary texts. ${ }^{7}$ Tryon was not licensed as a medical practitioner; nor was he shy of exhorting readers how to live their lives. But his conception of the body - and the 'operation' of substances upon it - drew powerfully on contemporaneous vernacular traditions of medical learning. His work suggests that historians of pre-Enlightenment addiction may have been too quick to neglect the insights of Renaissance medicine.

\footnotetext{
${ }^{3}$ Harry Gene Levine, 'The discovery of addiction: changing conceptions of habitual drunkenness in America', Journal of Studies on Alcohol, 39 (1978), pp. 143-74; reprinted in Journal of Substance Abuse Treatment, 2 (1985), pp. 43-57. Citations are from the 1985 reprint.

${ }^{4}$ Ibid., p. 47.

${ }^{5}$ Roy Porter, 'The drinking man's disease: the pre-history of alcoholism in Georgian Britain', British Journal of Addiction, 80 (1985), pp. 385-96, at p. 393.

${ }^{6}$ Virginia Berridge, Demons: our changing attitudes to alcohol, tobacco, and drugs (Oxford, 2013), p. 67; James Nicholls, The politics of alcohol: a history of the drink question in England (Manchester, 2009), pp. 64-8.

${ }^{7}$ Jessica Warner, “'Resolv'd to drink no more": addiction as a pre-industrial construct', Journal of Studies on Alcohol, 55 (1994), pp. 685-91, at p. 689; Rebecca Lemon, Addiction and devotion in early modern England (Philadelphia, PA, 2018), p. 15.
} 
Third, Tryon does not limit his observations to alcohols, noting the enslaving qualities of other commodities like coffee, tea, and tobacco. Historians, in contrast, have generally conflated addiction and alcoholism before the twentieth century. Levine set the frame, publishing for the Journal of Studies on Alcohol and specifically aiming to explain ideas behind the temperance and prohibition movements of the nineteenth and twentieth centuries. Porter, Warner, and Lemon have all followed suit, tracing back the antecedents of 'disease' models of addiction by focusing specifically on drunkenness. But Tryon not only appreciated the addictive power of coffee, tea, and tobacco; he also knew their rise in dietary prominence to be a recent phenomenon. In A way to health, long life and happiness (also published in 1691) he opined that 'It is not above sixty or seventy years ago since that only Gentlemen, and but a few of those took Tobacco, and then so moderately, that one Pipe would serve. ${ }^{8} \mathrm{~A}$ year later, he reminded his readers that "COFFEE is a new Liquor, invented by the Turks and Heathens ... which in few years is grown into much Esteem and Practice amongst the English' and that 'TEA is another Foreign Drink, the use whereof hath not been long known in England'. ${ }^{9}$ Even the market for alcohols had expanded, through the commercialization of traditional liquors and availability of newer - and 'improper' - distilled spirits. Just as in 'former days Canary was chiefly sold by the Apothecaries, and perhaps then when Adulteration was not so much in fashion, might be the best Cordial in their Shop', so 'the name and use of Brandy was not known till of late'. It was with the gift of hindsight that Tryon could now observe how 'the excess of all these things is become almost general amongst all sorts of People, even amongst those that count themselves most sober and Religious, and who should set Examples of Temperance to others'. ${ }^{10}$

This article picks up on some of the historiographical questions posed by Tryon, reconsidering medicalized notions of addiction and the body in the long seventeenth century. In so doing, it also explores the impact - or not of new and less familiar intoxicants on medical thinking and practices. 'Intoxicants' here refers to comestibles perceived by contemporaries to have intoxicating or 'befuddling' qualities that became prominent features of European palates during the era of expansion into the Americas and Asia - substances which have subsequently been recognized for their 'addictive' and intoxicating qualities. ${ }^{11}$ These included exotic commodities like tobacco, caffeines, and chocolate that, as Tryon noted, were largely untasted by most Europeans before 1600; the narcotic opium, valued in antiquity and, it

\footnotetext{
${ }^{8}$ Thomas Tryon, A way to health, long life and happiness, or, a discourse of temperance and the particular nature of all things requisite for the life of man as all sorts of meats, drinks, air, exercise \&c (London, 1691), pp. 126-7.

${ }^{9}$ Thomas Tryon, The good house-wife made a doctor, or, health's choice and sure friend being a plain way of nature's own prescribing to prevent and cure most diseases incident to men, women, and children by diet and kitchin-physick only (London, 1692), pp. 207, 215.

${ }^{10}$ Tryon, Way to health, pp. 123, 127.

${ }^{11}$ Phil Withington, 'Introduction: cultures of intoxication', Past \& Present, 222, Suppl. 9 (2014), pp. 3-33, at pp. 12-15; idem, 'Intoxicants and the invention of consumption', Economic History Review, 73 (2020), pp. 384-408, at pp. 386-7.
} 
seems, rediscovered by early modern physicians, at least in England; sugar, the mass production of which became an integral feature of the transatlantic slave economy; and the new and much stronger alcoholic spirits produced by distillation. ${ }^{12}$ As is well known, promoters of these goods tended to tout their medicinal qualities in order to legitimate and so increase their production and consumption, claiming both their efficacy as curatives in indigenous contexts and their translatability into Europe's humoral medical regimes. These claims were often met with scepticism. ${ }^{13}$

But while new intoxicants generated plenty of printed debate, much less is known about their material impact on English pharmacopoeia and their integration - or not - into the varieties of simple and compound medicines available in the 'medical marketplace' of physicians, apothecaries, and empirics. ${ }^{14}$ The lacuna is odd if only because a perennial debate among historians of medicine has been the extent to which healing practices did or did not change over the period. ${ }^{15}$ At the very least, the importation of so many new and reputedly affective substances begs the question how medical practitioners responded to the new intoxicants and, indeed, whether new conceptions of reflexive consumption were one kind of result.

This focus on bodies and substances - and the desires and needs they engendered - is inherently corporeal and material. But a final point of this article is that, as Barbara Rosenwein has argued for the history of 'emotions', corporeality only makes sense historically through the language and concepts by which people understood and discussed it. ${ }^{16}$ The history of addiction illustrates this entanglement - of corporeality/affect and language/concepts - in at least two respects. Most obviously, to argue that a physiological notion of 'addiction' existed in 1691 as well as 1891 is not at all to claim that these concepts were one and the same. On the contrary, the physiology of the body and how substances affected it were conceived and described very differently: the 'humoral' body of early modern physic was described through particular sets of lexicons and concepts, the body and mind of modern medical science

\footnotetext{
${ }^{12}$ The literature on each commodity is voluminous. For an introduction and overview, see David Courtwright, Forces of habit: drugs and the making of the modern world (Cambridge, MA, 2001).

${ }^{13}$ Sidney W. Mintz, Sweetness and power: the place of sugar in modern history (London, 1985), pp. 103-8; Brian Cowan, The social life of coffee: the emergence of the British coffeehouse (New Haven, CT, 2005), pp. 47-53; Jordan Goodman, Tobacco in history: the cultures of dependence (London, 1994), pp. 38-54; Markman Ellis, Richard Coulton, and Matthew Mauger, Empire of tea: the Asian leaf that conquered the world (London, 2015), pp. 49-51.

${ }^{14}$ Lucinda McCray Beier, Sufferers and healers: the experience of illness in seventeenth-century England (London, 1987), pp. 8-50; Patrick Wallis, 'Consumption, retailing and medicine in early-modern London', Economic History Review, 61 (2008), pp. 26-53, at pp. 27-8.

${ }^{15}$ Andrew Wear, 'Medical practice in late seventeenth- and early eighteenth-century England: continuity and union', in Roger French and Andrew Wear, eds., The medical revolution of the seventeenth century (Cambridge, 1989), pp. 294-320; Beier, Sufferers and healers, p. 7; Harold J. Cook, Matters of exchange: commerce, medicine, and science in the Dutch Golden Age (New Haven, CT, 2007), pp. 1, 41016; Patrick Wallis and Teerapa Pirohakul, 'Medical revolutions? The growth of medicine in England, 1660-1800', Journal of Social History, 49 (2016), pp. 510-31, at pp. 510-12.

${ }^{16}$ Barbara H. Rosenwein and Riccardo Cristiani, What is the history of emotions? (Cambridge, 2018), pp. 41-5.
} 
by others. Within both semiotic systems it was perceived possible to need to consume certain substances involuntarily and with grave dangers for bodily and mental health; but the physiological processes by which this happened were described and explained in different ways.

Second, and more particularly, the early modern history of the verb 'to addict' serves as a nice reminder that words and concepts are by no means synonymous: rather that words accumulate and lose meanings according to the contexts of their usage. Jose Cree has recently demonstrated that it was a 'textual community' of Protestant evangelicals who initially appropriated the Latin addicere into English from the later 1520s in order to discuss choices over doctrine and morality. ${ }^{17}$ As a synonym for verbs like 'devote', 'give', 'dedicate', and 'bind', 'addict' was evaluatively neutral - indeed, to addict oneself to study remained its most common referent up to 1700 - and throughout the period tended to revolve around two core meanings: 'a deep sense of attachment to another person or being, and a strong disposition for doing particular activities or practices'. ${ }^{18}$ From the middle of the sixteenth century the terminology seeped into wider usage, with 'addicted' established as an unremarkable feature of vernacular printed discourse by the 1590s (the term 'addiction' was only used from the 1630s, and then occasionally). ${ }^{19}$ Thereafter, long-term collocates of 'addict' and 'addicted' included behaviours relating to 'study', 'service', and 'religion', as well as 'pleasure', 'vice', and 'superstition', with the kind of behavioural choice dictating the term's evaluative force. One 'vice' invariably condemned by moralists - 'drunkenness' - emerged as an occasional object of addiction in the early seventeenth century, becoming a regular collocate after $1650 .^{20}$

Throughout this period the core meaning of 'addition' was binding attachment or fervent devotion to someone or something: addiction ultimately stemmed from choice rather than compulsion. ${ }^{21}$ However, in the later seventeenth century, medical writers nuanced and developed these meanings, occasionally using 'addict' as surrogate for the lexicon traditionally used to describe physical ailments. This was the language of 'custom' and, in particular, the process whereby a person's 'accustomed' ingestion created, quite literally, a 'second nature' that was in tension with healthy 'natural' instincts and rational decision-making. ${ }^{22}$ The significance of the language of custom is, of course, well known to social and economic historians of the early modern period. Custom was the 'lived-in environment of practices, inherited assumptions and rules' that constituted everyday lives, routines, relationships, and

\footnotetext{
${ }^{17}$ Jose Cree, 'Protestant evangelicals and addiction in early modern English', Renaissance Studies, 32 (2018), pp. 451-5; idem, 'The invention of addiction in early modern England' (Ph.D. thesis, Sheffield, 2018), p. 105.

${ }^{18}$ Cree, 'Protestant evangelicals', p. 462.

${ }^{19}$ Cree, 'Invention of addiction', p. 105.

${ }^{20}$ Ibid., p. 116; Warner, “'Resolv'd to drink no more”', p. 687; Lemon, Addiction and devotion, p. 84.

${ }^{21}$ Cree, 'Protestant evangelicals', pp. 455-7.

${ }^{22}$ Steven Shapin, 'Why was "custom a second nature" in early modern medicine?', Bulletin of the History of Medicine, 93 (2019), pp. 1-26, at p. 4.
} 
allocation of resources within communities. ${ }^{23}$ Moreover, because customs were known to carry prescriptive and proscriptive force - and could be contested, invented, and reinvented - the concept was also a key term of legal process and the popular political imagination. Less recognized is the fact that, as a term that primarily described social practices and their influence on behaviour and attitudes, custom was an organizing concept in most discourses devoted to establishing those interconnections - not least pre-modern physic. ${ }^{24}$ The argument of this article is that seventeenth-century vernacular medical writers not only explained notions of compulsive and involuntary consumption as the operation of 'custom', but they also expanded on how embodiment occurred. By 1700 , the language of 'addict' had begun to be used to describe the same ideas.

\section{II}

Healing in seventeenth-century England did not undergo a paradigmatic shift or 'revolution'. Although there were many kinds of medical practitioner, Lucinda Beier has noted that almost 'all healers and sufferers subscribed to a humoral view of disease and therapy. Illness and injury caused an imbalance of the body's idiosyncratic humoral complexion which was rectified by evacuation. ${ }^{25}$ This did not change over the period. Likewise, different traditions of medical lore and knowledge - whether herbal, astrological, classical, or chemical-were all 'directed at maintaining or restoring the equilibrium of the sanguine, choleric, melancholic and phlegmatic humours'. ${ }^{26}$ How they differed was in the selection of medicines to do it. Even the developing insights of experimental and empirical 'science' (to use that term in a broad sense) were accommodated within the humoral system, at least insofar as they were communicated to everyday practitioners and the reading public.

But that is not to say that the period did not also witness significant changes. This was a formative era in terms of the development of the 'professional' - and rivalrous - identities of physicians, surgeons, and especially apothecaries; it was also a tipping point in terms of the likelihood of wealthier householders seeking external and commercial medical care for serious illness. ${ }^{27}$ In the meantime, the agenda of translating medical knowledge into English, begun in the 1530s, continued apace, contributing to a reading public increasingly 'interested and comparatively well-informed on medical topics.' ${ }^{28}$ And, perhaps most significantly, Patrick Wallis has demonstrated that

\footnotetext{
${ }^{23}$ Keith Wrightson, 'The politics of the parish in early modern England', in Paul Griffiths, Adam Fox, and Steve Hindle, eds., The experience of authority in early modern England (New York, NY, 1996), pp. $10-46$, at pp. $22-3$.

${ }^{24}$ Shapin, 'Why was "custom a second nature"?'.

${ }^{25}$ Beier, Sufferers and healers, p. 31.

${ }^{26}$ Ibid.

${ }^{27}$ Harold J. Cook, The decline of the old medical regime in Stuart London (Ithaca, NY, 1986); Ian Mortimer, The dying and the doctors: the medical revolution in seventeenth-century England (Woodbridge, 2009).

${ }^{28}$ Beier, Sufferers and healers, p. 32; Paul slack, 'Mirrors of health and treasures of poor men: the uses of the vernacular medical literature of Tudor England', in Charles Webster, ed., Health, medicine, and mortality in the sixteenth century (Cambridge, 1979), pp. 237-73, at pp. 240-1, 272-3; Elaine
} 
'consumption of imported medical drugs exploded in the seventeenth century and continued growing more gradually over the eighteenth century' - so much so that the 'level of imports in 1699-1701 was 27 times higher than a century earlier'. ${ }^{29}$ This did not indicate a shift in treatments, as most of these drugs were already staples of Renaissance medicine. Rather it points to a significant hike in dosages per capita, which - when combined with lower pricing, proactive practitioners, and knowledgeable patients-suggests an 'increase in the consumption of medicine that extended far beyond the elite. ${ }^{30}$

These trends of professionalization, vernacularization, and the enhancement of the materia medica converged in the first publication of an English pharmacopoeia, in 1649. Pharmacopoeia were reference works detailing which medicines to use for particular ailments and how to make them. Modelled on classical templates and usually in Latin, they began to be published by societies of apothecaries in European cities from the middle of the sixteenth century. The first London pharmacopoeia was issued in 1618 by the College of Physicians to mark the formal incorporation of the Society of Apothecaries, which was given the monopoly over prescriptions under the authority of the college. It also coincided with the huge increase in imported drugs tracked by Wallis. Nicholas Culpeper subsequently published the Physical directory or translation of the London dispensatory in 1649 as a deliberate challenge to the physicians' power and as a contribution to 'the liberty of the subject' (the monarchy was abolished the same year). ${ }^{31} \mathrm{He}$ did so to enable apothecaries to practise their 'art' without obfuscation or interference, because 'All the Nation are already physicians', and because 'All the ancient physicians wrote in their mother tongues, and native language'. ${ }^{32}$ The translation was a huge success, appearing in twenty-two editions by the end of the century and inspiring numerous alternative versions.

Translated pharmacopoeia offer a quick and useful way of testing the impact of new intoxicants on vernacular medicine. Not only did they list 'authorized' simple and compound medicines and their ingredients (often with glosses and additions by particular translators). They were also directed at non-Latinate practitioners, as well as householders interested in collecting 'receipts' (recipes) and techniques. Table 1 accordingly shows the appearance of new intoxicants in three pharmacopoeia by medical practitioners committed to making physic socially accessible. They are Culpeper's Pharmacopeia Londinensis (1653), John Pechey's The London dispensatory (1694), and William

Leong, Recipes and everyday knowledge: medicine, science, and the household in early modern England (Chicago, IL, 2018), pp. 163-72.

${ }^{29}$ Patrick Wallis, 'Exotic drugs and English medicine: England's drug trade, c. 1550-c. 1800', Journal of Social History, 25 (2011), pp. 20-46, at pp. 21, 26.

${ }^{30}$ Ibid., pp. 37, 26, 34, 36.

${ }^{31}$ A physical directory or a translation of the London dispensatory made by the College of Physicians in London (London, 1649), sig. Ar. Revised as Nicholas Culpeper, Pharmacopeia Londinensis or the London dispensatory further adorned by the studies and collections of the Fellows (London, 1653). For Culpeper, see Patrick Curry, 'Culpeper, Nicholas (1616-1654)', ODNB.

${ }^{32}$ Physical directory, sig. Ar-v. 
Table I Intoxicants and common imported drugs in some vernacular pharmacopeia, 1650s to 1690s

\begin{tabular}{lccc}
\hline Substance & Culpeper I653 & Pechey I694 & Salmon I694 \\
\hline Tobacco & 21 & 6 & 35 \\
\hline Sugar & 208 & 96 & 328 \\
\hline Opium & 43 & 17 & 121 \\
\hline Coffee & 0 & 1 & 0 \\
\hline Tea & 0 & 1 & 0 \\
\hline Chocolate & 0 & 0 & 0 \\
\hline Wine & 336 & 142 & 637 \\
\hline Beer & 7 & 4 & 17 \\
\hline Ale & 7 & 0 & 70 \\
\hline Rhubarb & 49 & 22 & 44 \\
\hline Senna & 54 & 13 & 0 \\
\hline Jesuit's bark & 0 & 1 & 7 \\
\hline Sarsaparilla & 3 & 2 & 15 \\
\hline Wormseed & 7 & 0 & 1 \\
\hline
\end{tabular}

Sources: Culpeper, Pharmacopoeia Londinensis; Pechey, London dispensatory; Salmon, Pharmacopoeia Bateana.

Salmon's Pharmacopoeia Bateana, or, Bate's dispensatory (1694). ${ }^{33}$ Like Culpeper, Pechey was an antagonist of the College of Physicians, a committed empiricist (who recommended Galenic and chemical curatives as appropriate), and a translator of Thomas Sydenham, who pioneered observational and clinical methods. ${ }^{34}$ Salmon was an 'empiric' and prolific medical writer; his 1694 pharmacopoeia was a translation of the prescriptions of the royal physician George Bate, originally published in Latin by the apothecary John Shipton in $1688 .^{35}$ Taken together, the texts provide a fair indication of metropolitan prescriptive practice as it stood in 1650 and had developed by the 1690s.

The table shows the appearance of different substances across the three pharmacopoeia, with the new intoxicants compared both to traditional alcohols (wine, beer, and ale) and to five of the most common imported drugs counted by Wallis (rhubarb, senna, Jesuit's bark, sarsaparilla, and wormseed). Wallis also includes opium in his full sample of imported drugs, though not in his five-drug sample. ${ }^{36}$ The appearances of substances in the texts are not

\footnotetext{
${ }^{33}$ Culpeper, Pharmacopoeia Londinensis; John Pechey, The London dispensatory, reduced to the practice of the London physicians wherein are contain'd the medicines, both Galenical and chymical, that are now in use (London, 1694); William Salmon, Pharmacopoeia Bateana, or, Bate's dispensatory translated from the second edition of the Latin copy (London, 1694).

${ }^{34}$ Cook, Decline of the old medical regime, pp. 224-5, 240.

${ }^{35}$ Philip K. Wilson, 'Salmon, William (1644-1713)', ODNB.

${ }^{36}$ Wallis, 'Exotic drugs', pp. 33-4.
} 
always linked to ingredients of simples and compounds, as substances could be occasionally subject to more general discussion; neither do the figures necessarily indicate how often a curative might be prescribed (in the sense that a purgative like senna may have been quotidian and an opiate for pain more irregular). That said, the correlation between appearance and prescription is comparable across the three texts, suggesting at least two important trends. The most obvious - aside from the complete absence of caffeine and cocoa from the seventeenth-century apothecary's art - is that traditional alcohols and some of the new intoxicants were quite as medicinal as foreign drugs. Of these, there were two types: 'mixers' like wine, ale, and sugar that made medicines palatable as solutions and syrups and so on, and which were by far the most common ingredients of simples and compounds; and substances with an operational effect, such as tobacco and opium. In both respects, the significant increases in the import of wine, sugar, tobacco, and opium over the century coincided exactly with the rise in medical consumption indicated by drug imports (with opium straddling the two categories). ${ }^{37}$

Second, the prescription of tobacco and especially opiates must qualify Beier's claim that physic remained dedicated to evacuation across the century. Tobacco had a variety of uses, including different kinds of ingestion to produce sweats and relieve migraines and rheum; but the most emphatic recommendations in the pharmacopoeia involved external applications for pains and toothache. ${ }^{38}$ With opium there was no such ambiguity: it was valued as an analgesic. As the understated Pechey observed in 1697, 'For taking off Pain, Opium is the chief Medicine, and for causing Sleep, in doing of which it is of great Use. ${ }^{39}$ The key point here is that the economics of supply meant that neither intoxicant was easily available in England before the 1620 s. ${ }^{40}$ And while a popular medical writer like William Vaughan began to debate the merits of tobacco from the 1610s, his silence on opium is striking. ${ }^{41}$ Even as late as the 1650 s, Culpeper was clearly worried that the public's inexperience of opiates would cause more harm than good. ${ }^{42}$ But in this instance, familiarity did not breed contempt. By the 1690s, Pechey could observe that laudanum (the combination of opium and wine, taken either as a pill or as liquor) was 'one of the chief Instruments of Physick, whereby the Physician may do great things, and

\footnotetext{
${ }^{37}$ Ibid., pp. 26-9.
}

${ }^{38}$ William Vaughan, Approved directions for health, both naturall and artificiall derived from the best physitians as well moderne as auncient (London, 1607), p. 49; Culpeper, Pharmacopoeia Londinensis, pp. 17, 21-2, 108, 161, 166; Pechey, London dispensatory, pp. 41-2, 115; Salmon, Pharmacopoeia Bateana, p. 247, [2nd book], pp. 3, 12, 14, 23, 24, 80, 149.

${ }^{39}$ John Pechey, A plain introduction to the art of physick containing the fundamentals, and necessary preliminaries to practice ... (London, 1697), p. 175.

${ }^{40}$ Wallis, 'Exotic drugs', p. 42; Alexander Taylor, 'Tobacco retail licences and state formation in early modern England and Wales', Economic History Review, 72 (2019), pp. 433-58, at pp. 440, 447; Withington, 'Intoxicants and the invention of consumption', pp. 19-20.

${ }^{41}$ William Vaughan, Approved directions for health, both naturall and artificiall derived from the best physitians as well moderne as auncient (London, 1612), p. 80; idem, Directions for health, both naturall and artificiall approued and deriued from the best physitians, as well moderne as auncient ... newly enriched with large additions by the author (London, 1617), pp. 139-50.

42 Culpeper, Pharmacopoeia Londinensis, pp. 131, 152. 
gain himself a great Reputation, if he knows how to use them rightly, ${ }^{43}$ Salmon simply advised his readers to 'Esteem it as a jewel'. ${ }^{44}$ In a sample of 609 labelled apothecary drug jars pre-dating the nineteenth century, four of the top six recipes contained opiates (poppy, theriac, diascordium, and mithridatium). ${ }^{45}$ In terms of patient experience, the relatively recent possibility of reducing pain and inducing changes in consciousness may well have been transformative.

\section{III}

The proliferation of new intoxicants contributed to a defining feature of vernacular healing during the long seventeenth century: the enhancement and greater availability of England's materia medica and, by extension, the prospect of unprecedented relief from physical and emotional pain. This material expansion coincided with the semantic development recovered by Cree: namely the introduction of ideas about addiction (as devotion) into the vernacular during the 1530s, and the popularization of the language by the seventeenth century. ${ }^{46}$ How, then, did medical writers engage with this language in the era of its vernacular assimilation? The question is the more pressing because, while the big data evidence suggests that 'addict' retained its sense of voluntarism - to attach or devote - throughout the period, Warner and Lemon argue that the evidence of sermons and plays suggests otherwise. ${ }^{47}$ As Lemon puts it, Jacobean writers 'bolster their arguments with medical diagnoses, anticipating the modern notion of addiction as compulsive, pathological attachment'. ${ }^{48}$ To begin to test these claims, Tables 2.1 and 2.2 describe uses of 'addict' and 'addicted' in the printed works of eight writers on physic between the 1530s, when Thomas Elyot published his hugely influential Castle of health (final edition 1610), and the 1700s, with Thomas Tryon as the latest writer of medical handbooks. In between are Culpeper, Pechey, and Salmon - the compilers of vernacular pharmacopoeia - as well as earlier popularizers of physic: the late Elizabethan and Jacobean physicians and writers William Bullein, Edmund Gardiner, and William Vaughan. ${ }^{49}$ Table 2.1 shows who or what was addicted and Table 2.2 some of the substances or practices that were the focus or source of addiction. While the sample is by no means exhaustive, it is indicative of how different writers on physic used the language of 'addict' diachronically.

In line with the broader chronology sketched by Cree, the sample suggests that addict only became a term of medical discourse in the seventeenth century. Indeed, while Elyot and Vaughan used the language fairly heavily in their

\footnotetext{
${ }^{43}$ Pechey, Plain introduction, p. 334.

${ }^{44}$ Salmon, Pharmacopoeia Bateana, p. 304.

${ }^{45}$ Wallis, 'Consumption, retailing and medicine', p. 39.

${ }^{46}$ Cree, 'Protestant evangelicals', pp. 451-5.

${ }^{47}$ Cree, 'Invention of addiction', pp. 172-3.

${ }^{48}$ Lemon, Addiction and devotion, p. 13; Warner, “'Resolv'd to drink no more”', pp. 688-9.

${ }^{49}$ For Gardiner, see Margaret Pelling and Frances White, 'GARDINER, ?Edmund', in Physicians and irregular medical practitioners in London 1550-1640 (2004), http://www.british-history.ac.uk/no-series/ london-physicians/1550-1640/gardiner-edmund.
} 
Table 2.I Subjects of 'addict' and 'addicted' in the medical works of some vernacular writers, 1530 s to 1700

\begin{tabular}{|c|c|c|c|c|c|c|}
\hline & \multicolumn{2}{|c|}{ Human } & \multirow{2}{*}{ Organ } & \multirow{2}{*}{ Medicines } & \multirow{2}{*}{ Disease } & \multirow{2}{*}{ Total } \\
\hline & Voluntary & Involuntary & & & & \\
\hline $\begin{array}{r}\text { Thomas Elyot } \\
\text { (1530s/90s) }\end{array}$ & & & & & & 0 \\
\hline $\begin{array}{l}\text { William Bullein } \\
\text { (1560s) }\end{array}$ & & & & & & 0 \\
\hline $\begin{array}{l}\text { Edmund Gardiner } \\
\qquad(16 \mid 0 \mathrm{~s})\end{array}$ & & & & & & 0 \\
\hline $\begin{array}{l}\text { William Vaughan } \\
(1610 s)\end{array}$ & I & & & & & 1 \\
\hline $\begin{array}{l}\text { Nicholas } \\
\text { Culpeper } \\
\text { (1650s) }\end{array}$ & 8 & 2 & I & 8 & I & 20 \\
\hline $\begin{array}{l}\text { John Pechey } \\
\quad(1680 \mathrm{~s} / 90 \mathrm{~s})\end{array}$ & 4 & & & & & 4 \\
\hline $\begin{array}{l}\text { William Salmon } \\
(1680 \mathrm{~s} / 90 \mathrm{~s})\end{array}$ & 6 & 5 & & & & II \\
\hline $\begin{array}{c}\text { Thomas Tryon } \\
(1680 \mathrm{~s} / 90 \mathrm{~s})\end{array}$ & 10 & 1 & & & & II \\
\hline
\end{tabular}

contemporaneous non-medical works, Tables 2.1 and 2.2 show it hardly appears in their writings on physic. The single exception, in Vaughan's Approved directions for health, proves the rule. Responding to the question 'how wiveless bachelors, and husbandless maids, should drive away their unclean dreaming of venery at nights', Vaughan recommended 'refrain from wine, and venerous imaginations, and not use to lye in soft down beds. Secondly, they must addict themselves to read the Bible and moral Philosophy. ${ }^{50}$ Second, even after the term was adapted to physic it was deployed relatively infrequently. In comparison, for example, the early Stuart minister John Downame, who is extensively cited by both Warner and Lemon to demonstrate the 'disease' model of addiction, used the language ninety-three times across ten texts - double the amount of this entire sample of thirty-two texts (forty-seven uses). ${ }^{51}$ Third, the predominant inference of addict in medical contexts remained reflective (devotion or attachment) rather than reflexive (physiological compulsion). This was especially the case for alcohols and other intoxicants. Pechey warned, for example, that

\footnotetext{
${ }^{50}$ Vaughan, Approved directions for health (1612), p. 70.

${ }^{51}$ Word search of EEBO-TCP for 'addict' and variations, 30 Oct. 2019, https://quod.lib.umich.edu/ e/eebogroup/.
} 
Table 2.2 Objects of 'addict' and 'addicted' in some medical writings, 1530 s to 1700

\begin{tabular}{|c|c|c|c|c|c|c|c|c|}
\hline & \multirow{2}{*}{ Alcohols } & \multirow{2}{*}{ Coffee } & \multirow{2}{*}{ Foods } & \multirow{2}{*}{ Excess } & \multirow{2}{*}{$\begin{array}{l}\text { Behaviour } \\
\text { (negative) }\end{array}$} & \multirow{2}{*}{$\begin{array}{r}\text { Behaviour } \\
\text { (positive) }\end{array}$} & \multicolumn{2}{|c|}{ Ailments } \\
\hline & & & & & & & Mind & Body \\
\hline \multicolumn{9}{|l|}{ Elyot (1530s/90s) } \\
\hline \multicolumn{9}{|l|}{ Bullein (1560s) } \\
\hline \multicolumn{9}{|l|}{ Gardiner (1610s) } \\
\hline Vaughan (16I0s) & & & & & & 1 & & \\
\hline Culpeper (1650s) & & & $\mathrm{I}$ & 3 & 3 & $\mathrm{I}$ & 1 & $\mathrm{I}$ \\
\hline Pechey (1680s/90s) & 3 & & & & & & & I \\
\hline Salmon (1680s/90s) & 1 & & & 3 & 3 & & 2 & 2 \\
\hline Tryon (1680s/90s) & 3 & I & & 4 & 3 & & & \\
\hline
\end{tabular}

Sources: Thomas Elyot: The castell of health (reprints in 1595, 1610); William Bullein: Bulleins bulwarke of defence against all sicknesse (1562, 1579); Edmund Gardiner: Phisicall and approved medicines, aswell in meere simples, as compound observations (16II); William Vaughan: Approved directions for health (16I2); 70. Nicholas Culpeper: Galen's art of physick (1652), p. 63; Pharmacopoeia Londinensis (1653), p. 310; A new method of physick ... written in Latin by Simeon Partlicius, phylosopher, and physitian in Germany (1654), p. 492; Culpeper's last legacy left and bequeathed to his dearest wife, for the publicke good (1655), p. 83; The practice of physick ... being chiefly a translation of the works of that learned and renowned doctor, Lazarus Riverius (I655), p. 502; The idea of practical physick in twelve books ... written in Latin by John Johnston ... and Englished by Nich. Culpeper, Gent. ... and W.R. (I657), Pp. 6, 2I; The expert doctors dispensatory ... and these forms of remedies now before prescribed by the famous P. Morellus (I657), Pp. 188, 233, 235, 252, 324, 329, 334, 340; Culpeper's school of physick, or, The experimental practice of the whole art (I659), p. 345; Two treatises ... By Daniel Sennert, Doctor of Physick. Nicholas Culpeper, physitian and astrologer. Abdiah Cole, Doctor of Physick, and the liberal arts (1660), Pp. 17, 43, 46, 83; Platerus golden practice of physick ... By Felix Plater, chief physitian and professor in ordinary at Basil. Abdiah Cole, doctor of physick, and the liberal arts. Nich. Culpeper, gent. student in physick, and astrology (I664), p. I34; Blagrave's supplement or enlargement to Mr. Nich. Culpeppers English physitian (1674), p. 138; John Pechey: Collections of acute diseases: the second and third part (1688), p. 94; Collections of acute diseases, the fourth part (169I), pp. 83, 85; The store-house of physical practice being a general treatise of the causes and signs of all diseases afflicting human bodies (1695), p. 462; William Salmon, latrica, seu, praxis medendi, the practice of curing (I68I), Pp. 87, I73, 6I5, 624, 645; The anatomy of human bodies (1694), Pp. 2I, I46, I48, I83, 448; Ars chirurgica a compendium of the theory and practice of chirurgery (1698), p. 375; The family dictionary (1695); Thomas Tryon: Healths grand preservative (1682), Pp. I, 5, II; The planter's speech to his neighbours and country-men in Pennsylvania (1684), p. 25; The country-man's companion (1684), p. 125; A way to health (I69I), Pp. II, 25, 94, I87; Wisdom's dictates, or, aphorisms and rules (I69I), Pp. 74, I29; The good house-wife made a doctor (1692), pp. 174, 208; The way to save wealth (1695), pp. 62, 70; A discourse of water (1696), advertisement; A new method of educating children (1698), p. 24; Tryon's letter upon several occasions (1700), p. II. 
A Fever accompanied with many Peripneumonic Symptoms, invades yearly about the beginning of Winter, but oftner at the end of it; it chiefly seizes those that are of a gross Habit of Body, and middle aged, or (which oftner happens) those that are older, and too much addicted to Spirituous Liquors, especially to Brandy. ${ }^{52}$

Or as Tryon advised about coffee:

This sort of drink ought not to be used, but in a Physical way, by such as are troubled with Fumes and Distilling Vapours that fly up into the Head, and thereby stupefy the Senses; also it is profitable for such as have brought upon themselves such distempers by too large drinking of Wine and strong Drink, or by Weariness, Labour or Fasting, and for such as are troubled with the Head-Ach. But for others that are well, and not troubled with any of the aforesaid Inconveniences, they ought not to addict themselves to the frequent sipping of this Black Broth, though there is not so much mischief to be apprehended from it, as from strong spirituous drinks. ${ }^{53}$

That is not to say that there was no deployment of a physical sense of 'addict' in the medical literature. From the 1680s, Salmon explained that 'Sometimes the Tongue is resolved and remains [in a palsy] after an Apoplexy; chiefly in those, who during Health are addicted to Stammering' and that 'the watery humour being taken too copiously from the Brain, was the cause of [a patient] being so little addicted to sleep and drowsiness. ${ }^{54}$ He also relayed the opinion of the Swiss botanist Gaspard Bauhin that men 'by Nature' were 'more addicted to Gluttony' than women. ${ }^{55}$

Translating from ancient and continental authorities, Culpeper intimated two sources of compulsion: that people of a 'sanguine-phlegmatic complexion' were 'more addicted to the sports of Venus as sanguine are' and that those 'affected' by a 'Melancholy phantasm ... becomes wholly and only addicted to thoughtfulness. ${ }^{56}$ Even more strikingly, Culpeper as translator was as likely to use the language to describe the choices of medicines as humans, 'addict' in these instances combining the agency of the practitioner with the natural resonance between substances and parts of the body. With 'cephalical [head] lotions', for example, 'The UTILITY is great after purging, where the relics of the matter imparted is to be dissipated \& consumed; as also where the head is to be strengthened, and they are for the most part addicted only to the

\footnotetext{
${ }^{52}$ John Pechey, Collections of acute diseases, the fourth part (London, 1691), p. 84.

${ }^{53}$ Thomas Tryon, The good house-wife made a doctor (London, 1692), pp. 208.

${ }^{54}$ William Salmon, Iatrica, seu, praxis medendi, the practice of curing (London, 1681), pp. 615, 624.

${ }^{55}$ William Salmon, The anatomy of human bodies (London, 1694), p. 21.

${ }^{56}$ Nicholas Culpeper, Galen's art of physick ... translated into English, and largely commented on: together with convenient medicines for all particular distempers of the parts, a description of the complexions, their conditions, and what diet and exercise is fittest for them (London, 1652), p. 63; idem, The idea of practical physick in twelve books, written in Latin by John Johnston and Englished by Nich. Culpeper, Gent.... and W.R. (London, 1657), p. 21.
} 
cold distempers of the head and brain. ${ }^{.57}$ Likewise, 'The differences of Purges are various, for some are addicted to Phlegm, some to Choler, others to Melancholy, and some to watery humours, and they are all of the same natures with those humours they purge. ${ }^{58}$ Even bodily parts and diseases could addict - or not addict - in this sense of inherent synergy and attraction: "the Spleen being no ways addicted to concoction, binding Medicines do it harm, and not good'; 'Endemical Diseases by a certain perpetuity, are addicted to certain Places, Regions, and Cities, as Agues to the Fenny Countries in England. ${ }^{59}$ This was reflexive behaviour - albeit of animate matter rather than rational beings.

\section{IV}

The sample suggests that, while medical writers began occasionally to use 'addict' to describe physical ailments by the middle of the seventeenth century, it was not used to describe dependency on intoxicants. But this does not mean that Warner and Lemon are anachronistic to argue that medicine could diagnose intoxication as physiologically compulsive. Rather, they look at the wrong vocabulary - or, in the case of Lemon, conflate the capacity to addict (to attach and devote) with the social and physiological processes by which the resulting habits were understood to become embodied and reflexive. ${ }^{60}$ In her treatment of 'addiction as disease', for example, Lemon focuses on the sermonizing of Downame, who published an excoriating attack on drunkards in $1609 .{ }^{61}$ But while Downame certainly railed against those who 'addict themselves to much drinking', he used exactly the same vocabulary for all manner of life choices. ${ }^{62}$ In The second part of the Christian warfare, these included 'beauty', 'pleasure', phantastical pride', 'fashion', and 'voluptuous pleasures'. ${ }^{63}$ In his Annotations upon all the books of the Old Testament (focusing on Genesis), they included 'delicacy, varieties and plenty of provision', 'the wearing of an hairy garment', 'deeds of darkness', 'learning the Egyptian tongue', 'tillage' as a 'peaceable and quiet life', and so on. ${ }^{64}$ The list of addictions was almost interminable; but it was not a litany of diseases. For Downame,

\footnotetext{
${ }^{57}$ Nicholas Culpeper, The expert doctors dispensatory. The whole art of physick restored to practice [by Pierre Morel] (London, 1657), p. 188.

${ }^{58}$ Nicholas Culpeper, Culpeper's last legacy left and bequeathed to his dearest wife, for the publicke good, being the choicest and most profitable of those secrets which while he lived were lockt up in his breast, and resolved never to be publisht till after his death (London, 1655), p. 83.

${ }^{59}$ Culpeper, Pharmacopoeia Londinensis, p. 310; Nicholas Culpeper, A new method of physick: or, a short view of Paracelsus and Galen's practice ... written in Latin by Simeon Partlicius, phylosopher, and physitian in Germany (London, 1654), p. 493.

${ }^{60}$ Lemon, Addiction and devotion, pp. 82-6.

${ }^{61}$ Ibid., pp. 83-4.

${ }^{62}$ John Downame, Foure treatises tending to disswade all Christians from foure no lesse hainous then common sinnes; namely, the abuses of swearing, drunkennesse, whoredome, and briberie (London, 1609), p. 79.

${ }^{63}$ John Downame, The second part of the Christian warfare (London, 1611), pp. 117, 244, 380, 715.

${ }^{64}$ John Downame, Annotations upon all the books of the Old Testament (London, 1645), 'Annotations on the ... five books of Moses, and particularly on the first of them called Genesis'.
} 
what distinguished 'strong drink' from men's many other vices was not the decision to addict so much as the habitual and physiological consequences that could follow from the decision: 'First sin is committed, then practiced, and often practice bringeth custom, and custom becomes a second nature, and hath in it the force of a law which must be obeyed, not in courtesy but upon necessity. ${ }^{65}$

Steven Shapin has recently traced the venerability of custom as 'second nature' in physic, showing how the term accounted for how the 'non-naturals' of humoral medicine - diet, climate, the quality of air and water, sleeping patterns, habits of exercise and evacuations (including sexual release), the 'control of the passions of the soul (or emotions)'-moulded the body over time through its 'transactions with the environment'. ${ }^{66}$ Shapin also notes that this made for a relatively benign attitude to dietary infelicities, as it was recognized that force of habit created degrees of dependency which were dangerous to break. ${ }^{67}$ Even resolute reformers like Tryon acknowledged that you 'Do not pass immediately from a disordered kind of Life, to a strict and precise course, but do it by little and little'. This was because 'The Opinion of all Physicians' was that it is 'dangerous to be driven off forcibly from that which a Man hath been long accustomed to' ${ }^{68}$ In contrast, moralists like Downame appropriated the concept of custom and second nature in the early seventeenth century to warn against becoming addicted to drink.

But if the chronology of sermonizing discussed by Warner and Lemon is at all indicative, then it was, in fact, James's I's 1604 attack on 'this vile custom of tobacco taking' that made the trope available as moralistic-and distinctly unbenign - rhetoric. ${ }^{69}$ As England's new monarch expostulated:

many in this kingdom have had such a continual use of taking this unsavoury smoke, as now they are not able to forbear the same, no more then an old drunkard can abide to be long sober, without falling into an uncurable weakness and evil constitution: for their continual custom hath made to them, habitum, altera naturam. ${ }^{70}$

No matter the vitriol of monarchs and sermonizers, however, the concept of 'custom' in general and custom as 'second nature' in particular was, and remained, a crucial feature of seventeenth-century physic and dietetics, providing the primary lexicon with which to describe the intersection of behaviours, substances, and bodily processes. ${ }^{71}$ And it was out of this discursive

${ }^{65}$ Downame, Foure treatises, p. 93, cited in Lemon, Addiction and devotion, p. 82.

${ }^{66}$ Shapin, 'Why was "custom a second nature"?', p. 5.

${ }^{67}$ Ibid., p. 6.

${ }^{68}$ Thomas Tryon, The way to save wealth (London, 1695), p. 70.

${ }^{69}$ James I, A counterblaste to tobacco (London, 1604), sig. Br. See also Edmond Gardiner, Phisicall and approved medicines, aswell in meere simples, as compound obseruations ... With the true use of taking that excellent hearbe tabacco, aswell in the pipe by sume, as also in phisicke, medicine and chirurgerie (London, 1611), pp. 15-17.

${ }^{70}$ James I, Counterblaste to tobacco, sig. C3v.

${ }^{71}$ Shapin, “Why was "custom a second nature"?', pp. 3-5. 
tradition that Tryon developed his explanation as to why people became gripped by tastes, desires, and dependencies for ostensibly strange and ruinous substances.

Viewed in the round, 'custom' carried four meanings for vernacular medical practitioners and translators like Culpeper and Pechey. First, they subscribed to the general conviction that customs were the social practices by which individuals and groups of people did and said things in time and over time. But, in addition, they tended to imbue those practices with dietetic significance. Both writers were intrigued, for example, by 'the old Custom of saying God bless you to him that Sneezes; which some say came from hence, In the time of Gregory the Great there was an ordinary Disease of Sneezing by which the Patients died; albeit some say that Custom is more antient'. ${ }^{72}$ More recently, 'It is a custom now a-days to rub the dry Leaves of Tobacco between the fingers, and to snuff up the Powder: this fetches much humor from the Brain, and is at hand. ${ }^{73}$

Second, custom described the practices that structured people's days and the personal dietetic regimens (the non-naturals) that these entailed. In his translation of Joannes Jonstonus, Culpeper observed how 'time of eating'

varies according to the several Customs of natures. The Hebrews seem to have eaten twice a day. Among the Greeks even so long as since Homers days, their times of eating were distinguished into dinner and supper. The latter Grecians did eat oftener: The Romans had their Breakfast, dinner, afternoon's bever, their Supper, and Rere-supper. Our Age follows the Custom of the Romans, yet thousands there are, that content themselves, with a dinner and supper only. ${ }^{74}$

Taking a more experiential and observational approach, Pechey itemized for his readers the practices he developed to combat the dreaded 'stone'. Initially he deployed a strenuous regime involving laudanum, manna, and weekly purgation, continuing 'this method some Months, always purging of the same day of the Week; nor would I break this Custom, upon any account whatever. ${ }^{75}$ Thereafter he developed a 'Regimen and manner of Diet, which seems to me, proper for those that are troubled with either of these Diseases':

In the Morning when I rise, I drink a Dish or Two of Tea, and then ride in my Coach till Noon; when I return home, I moderately refresh my self with any sort of Meat of easy Digestion that I like; (for Moderation is

\footnotetext{
${ }^{72}$ Nicholas Culpeper, Abdiah Cole, and William Rowland, trans., The practice of physick in seventeen several books wherein is plainly set forth the nature, cause, differences, and several sorts of signs [by Lazare Rivière] (London, 1655), p. 113; Nicholas Culpeper and Abdiah Cole, Platerus golden practice of physick (1664), p. 12; John Pechey, The store-house of physical practice being a general treatise of the causes and signs of all diseases afflicting human bodies (London, 1695), ch. 41, 'Of sneezing'.

${ }^{73}$ Culpeper et al., Practice of physick, p. 6.

${ }^{74}$ Nicholas Culpeper, Idea of practical physick, p. 17.

${ }^{75}$ John Pechey, A collection of chronical diseases viz. the colick, the bilious colick, hysterick diseases, the gout, and the bloody urine from the stone in the kidnies (London, 1692), p. 147.
} 
necessary above all things) presently after Dinner every day, I drink somewhat more than a quarter of a Pint of Canary Wine, to promote the Concoction of the Meat in my Stomach, and to drive the Gout from my Bowels ...

And so on, and on. ${ }^{76}$

Custom described, thirdly, the more formal conventions, rituals, and knowledge of medical practice, often critically. Pechey recalled how 'Jesuit's Powder, about Twenty-Five Years ago ... first became Famous at London for curing Agues ... for very good reason, seeing these Diseases were seldom cured before'. However, 'not very long after, it was damned', largely 'because it being given a few Hours before the Fit, according to the received custom of that time, sometimes killed the Patient'. ${ }^{77}$ Culpeper was equally scathing about English medical practices: indeed, it was his frustrations with most facets of professional practice that justified his own prolific recourse to print. One irritant was how 'use and custom hath long been to place greatest value in strange Medicines, and the practice of the most doth ratify the same' ${ }^{78}$ But this predilection merely obscured systemic ignorance, as English practitioners were relentlessly hoodwinked by merchants and traffickers: 'The corruption of their Drugs, is it not so great, that in the light of all knowledge, scarce one is able to discern the right Bolus Armena, from the Ocre of Apulia ... with a number of other corruptions, which have gotten strength by custom of error? ${ }^{79}$ Even if genuine Ottoman drugs did reach the physician and apothecary, and they knew what to do with them, 'Our English Bodies, through the nature of the Region, our kind of diet and nourishment, our custom of life, are greatly divers from those of strange Nations, whereby arises great variety of humors and excrements in our bodies, from theirs. ${ }^{80}$

This was because, fourthly, 'Custom is a new nature, and things to which we have been long time accustomed, though bad, are not so troublesome as those to which we have not been used. ${ }^{81}$ As Culpeper clarified:

We must have a special Eye to custom, by the power whereof, some have fed on poison without hurt ... The worse, but more pleasing meat and drink, is to be preferred before that which is better, and not so delightful. For the Stomach greedily attracts, straitly embraces, and happily digests such kind of meats. ${ }^{82}$

Culpeper's personal choice of 'poison' was tobacco: he was so accustomed to smoking that it allegedly killed him. Pechey gave opium as another example. Noting how 'The Dose is often extraordinarily increased upon the account of

\footnotetext{
${ }^{76}$ Ibid., pp. 148-9.

77 Pechey, Collections of acute diseases, the fourth part, p. 39.

${ }^{78}$ Nicholas Culpeper, Culpeper's school of physick (London, 1659), p. 4.

${ }^{79}$ Ibid., pp. 11-12.

${ }^{80}$ Ibid., p. 18.

${ }^{81}$ Culpeper, Idea of practical physick, p. 24

${ }^{82}$ Ibid., p. 25.
} 
Custom', he rehearsed the familiar discrepancy between how 'the Turks, Persians, and other oriental People, take a Dram at a time, and they are so used to it, that they cannot abstain from it without hazarding their Lives, and incurring grievous Symptoms. But the Europeans use it only in Medicine, and in a less Dose. ${ }^{83}$

Indeed, the English were so unaccustomed to the power of opiates that Culpeper was ambivalent about revealing their secrets, explaining in his pharmacopoeia that 'I desire the ignorant to be very cautious in taking Opiates'. It was only 'the urgent importunity of friends moved me to set down the Doses; they may do wise men very much good, and therefore I consented: if people will be mad and do themselves mischief, I can but warn them of it, I can do no more'. ${ }^{84}$ Even laudanum - that 'gallant invention'- risked making 'a man sleep till dooms-day'. ${ }^{85}$ Pechey likewise acknowledged that 'Opiates, tho they are divine Medicines, and tho they do a great deal of good in many Diseases, yet an imprudent and unseasonable Use of them has been the Death of some. ${ }^{86}$ It was nevertheless the case that "Some People that have been afflicted with violent pocky Pains in the Joints, have taken Laudanum Opiatum in Pills, beginning at five Grains, and rising to half a Dram; and Authors relate, that some have taken above ten Drams daily, and yet have kept their Senses very well.' All of which demonstrated 'so much can Custom do'. ${ }^{87}$

\section{V}

In sharp contrast to 'addict', then, 'custom' saturated medical discourse. Not only did it provide the likes of Culpeper and Pechey with a critical perspective on the practices of patients and practitioners. It also served as an old language with which to describe the bodily effects of distinctly modern substances and appetites. But while description was one thing, explaining just how customs and habits became physically embodied was quite another. The habitual causation of certain ailments was widely recognized: squints, 'incontinence of urine', repetitive yawning, involuntary hacking, the bad posture of maids who spin, certain kinds of madness, bad dreams, and sleeplessness - these were examples of how repetitive behaviour, often acquired in childhood, shaped and remoulded the body and mind. Remedies were difficult, but possible: 'Custom as a second Nature is not easily changed, but by a contrary Custom. ${ }^{88}$ When it came to unseen physiological and cognitive processes, however, the moulding of custom was altogether more difficult to explain. It is striking, then, that when the physician Pechey and the autodidact Tryon attempted to do just this, they were each responding to the power of new intoxicants. It is equally striking that, in making their respective explanations,

\footnotetext{
${ }^{83}$ Pechey, Plain introduction, pp. 174-5.

${ }^{84}$ Culpeper, Pharmacopoeia Londinensis, p. 142.

${ }^{85}$ Ibid., p. 143.

${ }^{86}$ Pechey, Plain introduction, p. 179.

${ }^{87}$ Ibid., p. 175.

${ }^{88}$ Culpeper and Cole, Platerus golden practice, p. 48.
} 
they sketched contrasting humoral bodies: in the case of Pechey, an interdependent body and soul connected by humours, spirits, vapours, and consciousness; with Tryon, a more integrated corporeal space that, crucially, was constituted as a material microcosm of the natural world and its elements.

In his Plain introduction to the art of physic (1697), Pechy could only fathom the impact of narcotics in general terms, suggesting that 'the reason why Opium is devoured by the Turks in great Quantity, without any Harm, or however without any Danger of Life, is, because its Particles, by frequent Use, become agreeable and familiar'. Opiates worked, it seemed, 'by somewhat stupefying the Spirits' and making people 'amazed, so that they can undauntedly endure the Approaches of sensible things howsoever terrible they are ${ }^{89}{ }^{89}$ But he was more specific about alcoholic spirits and why "many eminent Men and Women, from the more frequent use of these, fall into this sad Custom, that it has become necessary to take a Draught often in a Day, either of some generous Wine or Spirit, or some strong Water, ${ }^{90}$ First encounters were often medicinal:

There are sundry occasions that bring Men into this bad Custom of sipping Cordial Liquors; as sudden Faintings, which are perhaps occasioned by Grief, toilsome Labour, vast Sweats, or acute Pain; also when one has eaten something that agrees not with his Stomach, and causes a weight and nauseousness, or when a Swooning, or Stupor, seems to be impendent through a spasmodic disposition, yea for many other causes it is usual to guzzle vinous Spirits. ${ }^{91}$

Thereafter, 'such Cordials being taken sometime, begin to be agreeable, and delight, the Mass of Blood being a little more freely expanded, and kindled by every taste of them, the whole Hypostasis of the Soul is thereby amplified, and excited into a kind of Ovation'. ${ }^{92}$ Although intoxication might subside,

the Soul remembering that Complacence, and being not content with her present State, affects the same again, and craves after more; wherefore upon every trouble of Body and Mind, as soon as the Spirits sink a little, a Cordial Draught is presently desired to raise them again; and so the Fabric of the Body is shattered. ${ }^{93}$

This was because

Nature being a little accustomed to extraordinaries, remains not long content with the same, and therefore they increase them daily, and repeat them oftener; so that at length the Stomach can bear, or digest nothing

\footnotetext{
${ }^{89}$ Pechey, Plain introduction, p. 179.

90 Ibid., pp. 159-60.

91 Ibid., p. 160.

92 Ibid.

93 Ibid.
} 
moderate, but still desires stronger and hotter; and the other Viscera, especially the Liver, are so dried and parched thereby, that the Blood being lessened as to its quantity, and depraved as to its Crasis, Diseases and Death supervene. ${ }^{94}$

The tragedy for Pechey was that 'this evil Custom [did not] prevail only among Drunken Companions, but sometimes learned Men, and fine and ingenious Women, that they may the more improve and exhilarate their Genius, sip often hot Spirits and Waters, or Aqua Vita, tho' it is improperly called so, and thereby undermine their Health'. ${ }^{95}$

Tryon also worried about distilled alcohols, along with caffeines and especially tobacco. His insight for explaining why people 'insensibly slip into excess' was that 'Man is truly a Microcosm, or little World, the Epitome of the whole Creation, and that all things have and find in him their simile, and consequently are able to influence and work upon him. ${ }^{96}$ The key term here and throughout his writings was 'simile' - the idea that all things external to the body had their equivalent within the body; that these equivalents were attracted to each other (rather like Culpeper's resonant and 'addicted' substances); and that, if certain similes were over-enlarged or stimulated, they became domineering and demanding. The concept was, in effect, a new twist on the 'non-naturals' of classical dietetics, though with any sort of 'soul' indistinguishable from a body that was, in turn, utterly enmeshed in its environment. ${ }^{97}$ This enmeshment left the body and its similes profoundly vulnerable to custom. For example, Tryon pointed out that if a Man accustom himself to Swearing, Lying, Jesting, Jeering, or Laughter, in short to any Vanity or Vice whasoever, it will become essential or all one with him, and he will be in pain if he be not practising it'. It followed that

if outward Employments and Communications have such great power over our Desires and Inclinations, how much more must Meats and Drinks, by whose Vertue and Nourishment the Blood and Spirits (which sway the dispositions of the whole Man) are continually maintained, and Life itself continued, Food and Nutriment being the bond of both the inward and outward Nature. $^{98}$

This philosophy led Tryon to take a number of dietary decisions that were unconventional at the time, including vegetarianism and distrust of hot food. It also made him particularly hostile to tobacco, which for him epitomized how 'the continual use of such things have awakened their Similes in the Stomach, and that requires their continuation'. ${ }^{99}$ Although initially 'most unpleasant and

\footnotetext{
94 Ibid.

${ }^{95}$ Ibid., p. 161.

96 Tryon, Wisdom's dictates, pp. 128-9.

97 Shapin, 'Why was “custom a second nature”?', p. 5.

98 Tryon, Wisdom's dictates, p. 130.

99 Tryon, way to health, p. 52.
} 
loathsome ... through Custom, and by degrees, it hath awakened its Simile in the Elements of the Body, and made that Quality strong, which at the first taking of it was weak, or lay as it were hid under the Qualities that did predominate'. ${ }^{100}$ Tryon stressed that it was not corporeal simile or even physic that induced people to 'addict' themselves to tobacco in the first instance:

Most People that smoke Tobacco, in the beginning forced Nature, and made her bow to their Inclinations, not for any Distemper, but of a vain wanton Humour, because of late 'tis grown the fashion, and many Thousands have strained and hurt their Health, and brought many Inconveniences upon themselves, merely to follow this brutish Mode. ${ }^{101}$

Tryon declared that, in truth, however, 'the constant taking of Tobacco is nothing else but the constant taking of Physick, though through Custom and Use the same (as likewise the highest Poisons) may be made familiar to Nature'. The consequence physically was that it 'proves as great a difficulty to Refrain it, as it was to make it Friendly at the first taking, or rather more'. ${ }^{102}$ But enslavement did not stop with individuals. Rather 'Children that are begot by Persons, that have accustomed themselves to the common use of these unnatural things, contract a kind of insensible Affinity with such things, as proceeding from the like matter and Essences, so ... it would prove a very difficult thing for them to refrain there-from.' It was already clear that 'every succeeding Age doth more easily and familiarly, and with the less difficulty receive these evil Customs and Habits, till in time they become almost Natural, and thence humane Nature in general becomes weaker and decayed'. ${ }^{103}$ It was not just bodies that became accustomed, but whole populations.

\section{VI}

'Would not', Tryon asked, 'all this seem most Abominable, and be counted a very great Evil and Intemperance, if it were not a Custom? ${ }^{104}$ Historians have long known this ancient language as both a category of social description and a tool of social legitimation, one used by all sorts of early modern people to understand and justify what they did, said, and owned. This article has argued that, for practitioners of physic, custom played a further role, describing and in some instances explaining how reflective decisions 'to addict' to certain practices became, almost implacably, embodied and reflexive dependencies. It did so in the face of a century of medical and dietary change that was driven, first and foremost, by the import of new drugs and intoxicants. While observers and moralists remained deeply concerned about traditional and

\footnotetext{
100 Ibid., p. 80.

${ }^{101}$ Ibid., p. 126.

102 Ibid., p. 81.

103 Ibid., p. 133.

104 Ibid., p. 128.
} 
evolving forms of drunken excess, it was tobacco, spirits, and opium that most precipitated analyses by medical writers. Perhaps unsurprisingly, medical discourse accordingly proved an important crucible for early modern conceptions of consumption and, by extension, offers new and historicized perspectives on the longer, trans-historical history of addiction.

Although there is no space here to discuss these perspectives in any detail, two points stand out. The first is the dramatic switch, so to speak, between modern and early modern substances. Virginia Berridge has argued that tobacco was an outlier in debates about addiction as disease and inebriation in the nineteenth century and only began to be treated 'scientifically' in these terms from as late as the 1970 s. ${ }^{105}$ In the century after its introduction to Europe, in contrast, tobacco was the catalyst for enquiries into custom and second nature more generally. Second, the great puzzle for early modern physicians was not whether consumption could be compulsive: clearly it was. Rather, it was the circuitous tension between choosing to addict to certain kinds of practice and coping with the second natures that those practices might engender: when, in any person's experience, did reflective preferences become embodied, via custom, as reflexive dispositions and naturalized necessities? Simply conflating the two processes is misleading and anachronistic; but, clearly, they were related and reinforcing, with practices - customs - at once structuring social behaviour and shaping bodily processes. Indeed, in one telling passage from 1691, Pechey used 'addicted' in the conceptual space usually filled by 'accustomed', noting

we must carefully observe, that 'tis by no means safe to forbid the drinking of Spirit Wine, and such Liquors all of a sudden, when the Patient has been a while addicted to them, but they must be left off gradually, for there is danger of a Dropsy from a hasty and abrupt change, which ought to be observed in all Diseases that come on this occasion. ${ }^{106}$

This marked, perhaps, the shape of things to come. It certainly anticipated the eclipse of custom - and custom as second nature - by the nineteenth century. Shapin eloquently notes the marginalization of the humoral system in 'folkmedical genres' and the corresponding rise of the 'full armamentarium of epidemiological statistics, the citation of risk factors, facts about metabolism, and pathological findings'. ${ }^{107}$ In the meantime, 'addict' not only survived the 'rise of scientific medicine' but became the meta-term of social and medical analysis: a newer word to describe an old and evolving problem.

Acknowledgements. This article forms part of Intoxicants and early modern European globalization: spaces, practices, material culture, a special issue resulting from a workshop series, held in 2017 at the Victoria and Albert Museum and in 2018 at the Beinecke Library, Yale University. I would like to thank the ESRC and the Beinecke for their support and also all the participants of both conferences (including the other contributors to the issue) for their valuable insights and feedback, and

\footnotetext{
${ }^{105}$ Berridge, Demons, pp. 69, 195, 199.

${ }^{106}$ Pechey, Collections of acute diseases, the fourth part, p. 86, emphasis added.

${ }^{107}$ Shapin, 'Why was “custom a second nature"?', p. 25.
} 
especially my co-editor, Kathryn James. Thanks also to Steven Shapin, Cathy Shrank, Paul Slack, and Keith Wrightson for reading earlier drafts of the article.

Funding Statement. The workshop series at the Victoria and Albert Museum was funded by the ESRC 'Intoxicants \& Early Modernity Project'. Thanks also to the HERA 'Intoxicating Spaces' project for a subsequent tranche of funding and support.

Cite this article: Withington P (2022). Addiction, Intoxicants, and the Humoral Body. The Historical Journal 65, 68-90. https://doi.org/10.1017/S0018246X21000194 